\title{
Challenges of Regulatory Environmental Risk Assessment for Human Pharmaceuticals with Focus on Antibiotics
}

\author{
R. Arno Wess*, Thomas Schmidt, and Stefan Höger
}

\begin{abstract}
Just recently the problem of pharmaceutical residues in the environment has been emphasized by OECD. Especially antibiotics are of concern due to their widespread use and diverse modes of actions including ones that can affect the photosynthetic activity of primary producers and subsequently primary biomass production and carbon dioxide fixation. The EU regulatory authority, the European Medicines Agency (EMA), has therefore proposed to implement a new tailored environmental risk assessment scheme, published in a new draft guideline 2018. Threshold effect levels to three fixed representative species of green algae and cyanobacteria will be required. This article reviews and compares the contamination of waters with antibiotics in Switzerland and Germany and also presents an overview of published effect data on eukaryotic algae and prokaryotic cyanobacteria in order to discuss the representativeness of the selected species. Since no full datasets as demanded by the EMA were publically available yet, the gaps for four antibiotics have been experimentally completed. In summary the results support the species selection of the EMA published in the revised draft guideline, however it remains unclear whether diatoms should also be considered.
\end{abstract}

Keywords: Antibiotics · Environmental Risk Assessment (ERA) · EU regulation · Human pharmaceuticals · Measured Environmental Concentration (MEC)



$\boldsymbol{R}$. Arno Wess studied biology, chemistry and toxicology, contributing to an ecotoxicology lexicon and entered (eco)toxicological data in AIDA, an IUCLID database precursor. His dissertation was a QSAR model development at the Goethe University Frankfurt, Germany. He worked for the pharmaceutical industry and a start-up developing an object-oriented intelligence database for (eco) toxicological modes of action and since 14 years for GLP-laboratories, starting 11 years ago in a regulatory consulting team. 2018 he joined IES to focus on market opening for the pharmaceutical industries. Focussing on ecotoxicology, environmental fate, and regulatory legislation, his special knowledge comprises difficult substances and mixtures, computational toxicity category approaches and read-across. Arno is member of SETAC, SST, and the Senckenberg Society for Nature Research.

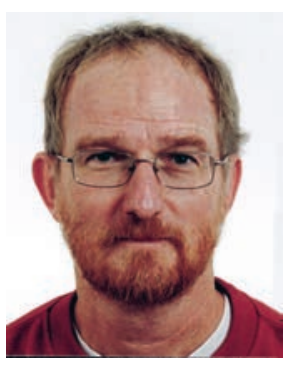

Thomas Schmidt studied biology at the University of Würzburg, Germany, and is specialized in animal ecology, ecological botany, pharmaceutical biology and biochemistry. He works as study director in terrestrial ecotoxicology (non-target arthropods, pollinators, soil organisms, dung organisms) and aquatic ecotoxicology (sediment organisms) under GLP since 2002 and developed advanced statistical skills for determination of NOEC/LOEC and calculation of ECx. In addition, he is a regulatory expert for environmental risk assessments of human pharmaceuticals and plant protection products and participates actively at meetings of SETAC and IOBC since many years.

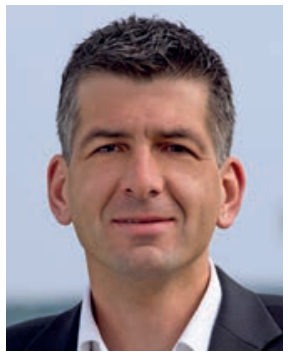

Stefan Höger studied biology at the University of Konstanz, Germany. During his PhD (2000-2004) he focused on the issues of drinking water treatment of cyanobacterial-loaded surface waters and the consequences for human health in Switzerland, Germany and Australia. After completing his $\mathrm{PhD}$ he coordinated the toxicological section of the EU project PEPCY (20042006). Since 2007 he is working in the contract research industry in Switzerland. He worked and is working there as a study director, department head, GLP test facility manager, COO and CEO. His field of expertise covers ecotoxicology, toxicology and regulatory know-how. Stefan is member of SETAC and SCS.

\section{Introduction}

According to a recent OECD publication, [1] pharmaceutical residues in freshwater are a challenge that must continuously be tackled taking advances in our knowledge into account. The report stresses the need for a better understanding of the effects of pharmaceuticals in the environment, calls for greater international collaboration and accountability distribution, and suggests policy actions to prevent and remedy the problem across the pharmaceutical life cycle.

The harmonized structure for registration dossiers of medicinal products (Common Technical Document, CTD) puts the 
Environmental Risk Assessment (ERA) in Module 1.6, which is a nation-specific chapter. It is not harmonized and national legislation applies in terms of content and requirements. While Switzerland has no detailed specific regulation for the content and data needs, in the European Union (EU) the European Medicines Agency (EMA) has released a binding guideline, ${ }^{[2]}$ which is going to be adapted to the technical progress. ${ }^{[3]}$

During the EU ERA for Human Medicinal Products (HMP) ${ }^{[2,3]}$ every substance is evaluated using the lowest toxicity threshold concentration from the first three trophic levels of the food chain. This concentration is then divided by a safety factor resulting in the Predicted No-Effect Concentration (PNEC). The Predicted Environmental Concentration (PEC) is calculated according to models given in the guidelines ${ }^{[2,3]}$ and then divided by the PNEC. The resulting Risk Quotient (RQ) is thus the PEC/PNEC ratio and should be $<1$ to indicate risk control.

Apart from the (cross-) resistance problems, antibiotics - as designed to target bacteria (sharing a prokaryotic cell structure) - may harm primary producers, which are represented by monocellular photosynthetically active test organisms according to the guidelines ${ }^{[2,3]}$ in the ERA. Antibiotics may particularly affect/ harm the cyanobacteria (Cyanophyta; also called blue-green algae) as well as bacteria of microorganism communities in sewage sludge, which are essential for the functioning of Waste Water Treatment Plants (WWTP). Green algae (Chlorophyta) and diatoms (Bacillariophyta), although representing eukaryotic cells, may also be quite sensitive, particularly if bacterial target structures are present in their organelles that bear similarities to prokaryotic cells, i.e. plastids (e.g. the photosynthetically active chloroplasts) or mitochondria.

While the (cross-) resistance potential is not yet regulated, the protection of WWTP is addressed experimentally by the sum endpoint 'activated sludge respiration inhibition' in a study compliant to the OECD Test Guideline (TG) $209,{ }^{[4]}$ obligatory for ERA in the EU according to the guideline of EMA.[2,3] This test is based on the premise that the whole microorganism community may be altered by the loss of intoxicated most sensitive species, but can maintain its function due to the increase of more tolerant ones as long as the respiration rate remains unchanged.

Given the ecological role of primary producers, i.e. performance of photosynthesis and thus production of oxygen, binding carbon dioxide, and organic matter biosynthesis, their pivotal role in the biosphere is obvious. These biota, potentially affected by low concentrations of antibiotics, represent not only the two existing basic cell types (eukaryotes and prokaryotes) but also a large number of species. This makes it difficult to select the best representative species for the regulatory ERA testing. Accordingly, the existing EU ERA guideline ${ }^{[2]}$ prescribes no preferred test species, but clarifies that for 'antimicrobials' a cyanobacterium should be used.

Since 2006, when the first EU ERA guideline ${ }^{[2]}$ entered into force, an ERA was required for the registration dossier of all new HMP or, in case of major changes, also for existing products (socalled 'type II variations'). With the submitted dossiers data became increasingly available to the EU authorities in the meantime. On this basis, a more comprehensive approach seemed desirable for antibiotics. Due to the large interspecies differences experienced by the authorities reviewing the submitted dossiers and as also evidenced in the literature, the EMA guideline draft of $2018^{[3]}$ foresees newly two specific cyanobacterial and one green alga species (as stated in Table 3), while the trophic level of secondary or tertiary consumers, in ERA generally represented by fish, is not required any more in the specific case of antibiotics.

The publically available data do not yet comprise full primary producer datasets in agreement with the new draft guideline. Nonetheless such an overview would be particularly interesting when discussing the planned changes of the guideline. ${ }^{[3]}$
The clinical spectrum defined for the medical practice of antibiotic treatments distinguishes between the two major groups of bacteria, i.e. gram-positive and gram-negative ones, depending on the structure of their cell envelope and indicated by the outcome of the gram staining method. ${ }^{[5]}$ As cyanobacteria are gram-negative, ${ }^{[6]}$ strong effects of antibiotics clinically recommended for the treatment of infections caused by gram-negative bacteria seem likely. Consequently, two out of the three suggested species in the new tailored assessment approach for antibiotics in the EU[3] are cyanobacteria.

In order to test the appropriateness of the suggestions in the new guideline, we selected four antibiotics, clinically not recommended for infections usually caused by gram-negative bacteria. For these antibiotics, indication for testing specific (gram-negative) cyanobacterial toxicity is not self-evident. Therefore, the intention was to see whether the new scheme is appropriate also in such a case.

Using literature data and complementary new test results, we present four full data sets in agreement with the guideline draft requirements ${ }^{[3]}$ to enable a discussion of the new approach. As an evaluation in this context should consider antibiotics actually occurring in our environment, this publication also gives an overview on the Measured Environmental Concentrations (MEC) of antibiotics in surface fresh waters of Switzerland and Germany.

In addition effect values on eukaryotic algae and prokaryotic cyanobacteria were also retrieved from the literature in order to compare with the species selection of the guideline draft, ${ }^{[3]}$ and to assess the general risk posed by antibiotics in these countries.

\section{Literature Surveys}

\subsection{Exposure: Measured Environmental Concentrations (MEC) of Antibiotics in Surface Waters of Switzerland and Germany}

Methods: The occurrence of analytically measured antibiotics in the aquatic environment of Switzerland (i.e. rivers, lakes) was surveyed in a semi-quantitative literature research. The keywords 'antibiotic AND water', 'antibiotic AND lake' and 'antibiotic AND river' in PubMed resulted in nine relevant publications for Switzerland. ${ }^{[7-15]}$ For comparison purposes ten publications from Germany were added. ${ }^{[16-25]}$ Measured concentrations for 16 and 29 antibiotics were retrieved from the Swiss and German studies, respectively. The data were reported as mean or median values or as a range of minimum and maximum values resulting in 108 and 149 measured values from three different compartments (surface water of rivers and lakes, but also influents and effluents of WWTPs) in Switzerland and Germany, respectively (Table 1).

Maximum values were either extracted directly from the respective publication or calculated as mean plus two times the standard deviation. In addition, the use of the antibiotics as human and/or veterinary antibiotic is given in Table 1 as defined according to the list of authorized active substances available from Swiss Medic for the Federal Office of Public Health of Switzerland (status: 31 October 2019) and the drug information data base PharmNet.Bund of the Federal Ministry of Health of Germany (status: 27 June 2019).

Results: The detected antibiotics are presented in Table 1. In Switzerland and Germany, seven of the ten most frequently detected antibiotics were identical, whereas data on norfloxacin and metronidazole were only available for Switzerland and data on amoxicillin and doxycycline only for Germany. The most frequently detected antibiotics (i.e. more than ten times) were ciprofloxacin, norfloxacin and clarithromycin in Switzerland and sulfamethoxazole, trimethoprim, clarithromycin, erythromycin and roxithromycin in Germany. The maximum measured concentration of an individual antibiotic substance in Switzerland was $161 \mathrm{ng} / \mathrm{L}$ (norfloxacin), $3500 \mathrm{ng} / \mathrm{L}$ (clarithromycin) and 
Table 1. Numbers of analytical detections of antibiotics and their metabolites from surface waters and from influents and effluents of waste water treatment plants in Switzerland ( $\mathrm{n}=9$ studies) and Germany ( $\mathrm{n}=10$ studies).

\begin{tabular}{|c|c|c|c|c|c|c|c|c|c|c|c|c|}
\hline \multirow[t]{2}{*}{ No. } & \multicolumn{6}{|c|}{ Germany } & \multicolumn{6}{|c|}{ Switzerland } \\
\hline & Antibiotic & use & 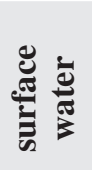 & 氖 & 氖 & $\mathbf{n}$ & Antibiotic & use &  & : & 를 & $\mathbf{n}$ \\
\hline 1 & Sulfamethoxazole & hum/vet & 9 & 2 & 9 & 20 & Ciprofloxacin & hum & 3 & 1 & 15 & 19 \\
\hline 2 & Trimethoprim & hum/vet & 6 & 1 & 6 & 13 & Norfloxacin & hum & 3 & 1 & 15 & 19 \\
\hline 3 & Clarithromycin & hum & 4 & 2 & 5 & 11 & Clarithromycin & hum & 4 & 2 & 6 & 12 \\
\hline 4 & Erythromycin & hum/vet & 6 & 1 & 4 & 11 & Sulfamethoxazole & hum & 3 & 2 & 3 & 8 \\
\hline 5 & Roxithromycin & hum & 4 & 2 & 5 & 11 & Azithromycin & hum & 3 & 2 & 2 & 7 \\
\hline 6 & Clindamycin & hum/vet & 3 & 2 & 3 & 8 & Trimethoprim & hum/vet & 3 & 2 & 2 & 7 \\
\hline 7 & Ciprofloxacin & hum & 2 & 2 & 2 & 6 & Roxithromycin & hum & 0 & 1 & 5 & 6 \\
\hline 8 & Amoxicillin & hum/vet & 1 & 2 & 2 & 5 & Clindamycin & hum/vet & 1 & 1 & 2 & 5 \\
\hline 9 & Azithromycin & hum & 1 & 2 & 2 & 5 & Metronidazole & hum/vet & 2 & 1 & 2 & 5 \\
\hline 10 & Doxycycline & hum/vet & 1 & 2 & 2 & 5 & Ofloxacin & hum & 2 & 1 & 2 & 5 \\
\hline 11 & Piperacillin & hum & 1 & 2 & 2 & 5 & Erythromycin & hum & 1 & 1 & 2 & 4 \\
\hline 12 & Ofloxacin & hum & 1 & 1 & 2 & 4 & Sulfadimethoxine & vet & 1 & 1 & 1 & 3 \\
\hline 13 & Sulfadiazine & hum/vet & 1 & 0 & 3 & 4 & $\begin{array}{l}\text { Sulfamethazine } \\
\text { (Sulfadimidine)* }\end{array}$ & vet & 2 & 0 & 0 & 2 \\
\hline 14 & Ampicillin & hum/vet & 1 & 1 & 1 & 3 & $\begin{array}{l}\text { Sulfamethoxazole- } \\
\text { N4acetyl }\end{array}$ & hum/vet & 1 & 1 & 0 & 2 \\
\hline 15 & Chloramphenicol & hum/vet & 1 & 0 & 2 & 3 & Sulfapyridine & vet & 1 & 1 & 0 & 2 \\
\hline 16 & Dicloxacillin & hum & 1 & 1 & 1 & 3 & Sulfathiazole & vet & 2 & 0 & 0 & 2 \\
\hline 17 & Flucloxacillin & hum & 1 & 1 & 1 & 3 & & & & & & \\
\hline 18 & Mezlocillin & hum & 1 & 1 & 1 & 3 & & & & & & \\
\hline 19 & Oxytetracycline & hum/vet & 1 & 1 & 1 & 3 & & & & & & \\
\hline 20 & Spiramycin & hum/vet & 1 & 1 & 1 & 3 & & & & & & \\
\hline 21 & Sulfadimidine & vet & 1 & 1 & 1 & 3 & & & & & & \\
\hline 22 & Tylosin & hum/vet & 1 & 1 & 1 & 3 & & & & & & \\
\hline 23 & Cefotaxime & hum & 0 & 1 & 1 & 2 & & & & & & \\
\hline 24 & Cefuroxime & hum & 0 & 1 & 1 & 2 & & & & & & \\
\hline 25 & $\begin{array}{l}\text { Clindamycin- } \\
\text { sulfoxide }\end{array}$ & hum & 0 & 1 & 1 & 2 & & & & & & \\
\hline 26 & Levofloxacin & hum & 0 & 1 & 1 & 2 & & & & & & \\
\hline 27 & Penicillin V & hum/vet & 0 & 1 & 1 & 2 & & & & & & \\
\hline 28 & Sulfamethizole & hum & 0 & 1 & 1 & 2 & & & & & & \\
\hline 29 & Vancomycin & hum & 0 & 1 & 1 & 2 & & & & & & \\
\hline
\end{tabular}

Substances in italics were not authorized in 2019. * = Sulfamethazine [USP] and Sulfadimidine [INN] are synonyms. hum/vet $=$ human and veterinary use.

$2400 \mathrm{ng} / \mathrm{L}$ (clarithromycin) for surface waters, influents and effluents, respectively, and in Germany $1700 \mathrm{ng} / \mathrm{L}$ (erythromycin), $2204 \mathrm{ng} / \mathrm{L}$ (sulfamethoxazole) and $8263 \mathrm{ng} / \mathrm{L}$ (sulfamethoxazole) for surface waters, influents and effluents, respectively (Fig. 1). The reported maximum values for mean or median concentrations in Switzerland were $14 \mathrm{ng} / \mathrm{L}$ (clarithromycin) and $430 \mathrm{ng} / \mathrm{L}$ (norfloxacin) for surface waters and effluents (no values for influents available) and in Germany $150 \mathrm{ng} / \mathrm{L}$ (erythromycin), $515 \mathrm{ng} / \mathrm{L}$ (sulfamethoxazole) and $2460 \mathrm{ng} / \mathrm{L}$ (sulfamethoxazole) for surface waters, influents and effluents (Fig. 1).
This literature survey points towards three characteristics of antibiotics in environmental samples: firstly, the variability of antibiotics is high (ranging from below the limit of detection in many surface water samples to up to $8263 \mathrm{ng}$ sulfamethoxazole/L in effluents) and mainly dependent on the location of sampling.

Secondly, the concentrations found in surface water samples are, as expected, lowest followed by higher concentrations in WWTP effluents and the highest concentrations in WWTP influents. It should be noted that some antibiotics were analysed at higher concentrations in effluents compared to influents (e.g. 
A

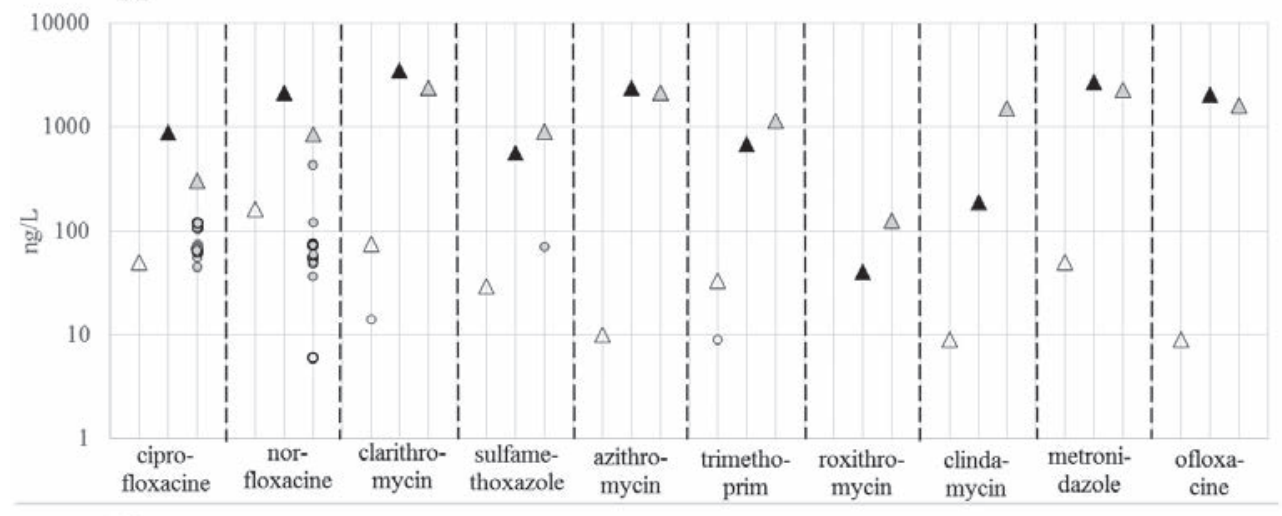

B

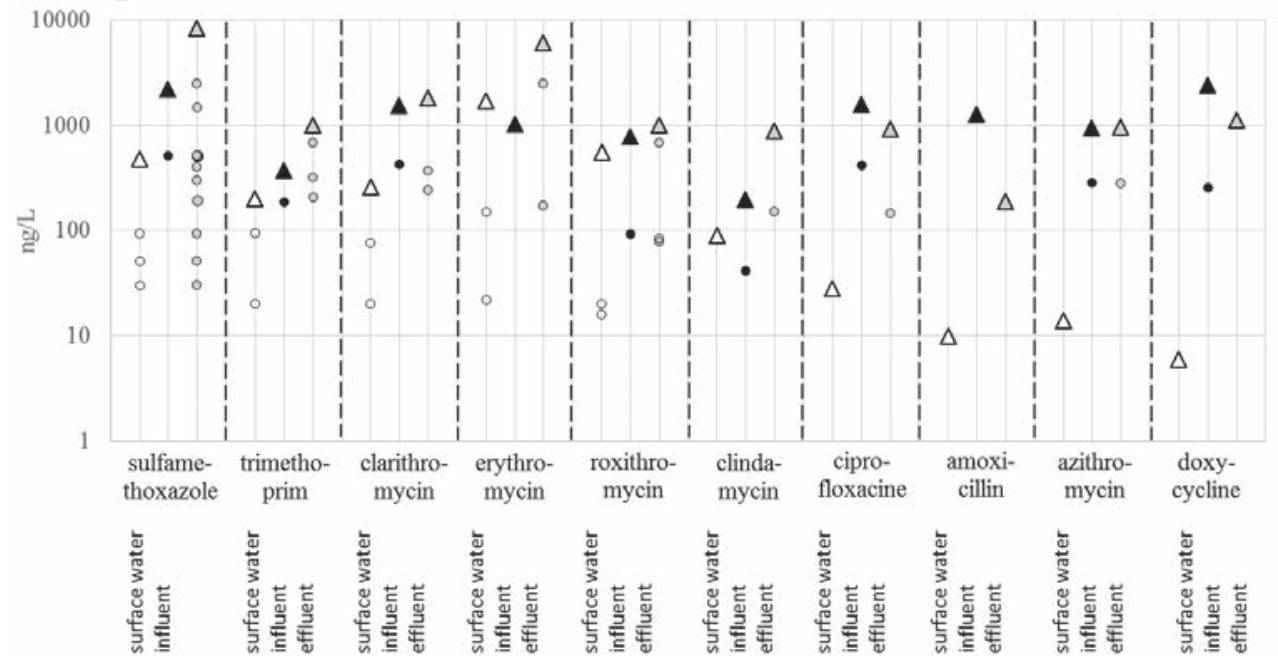

Fig. 1. Analytically determined concentrations of the ten most frequently found antibiotics in surface waters of river / lakes (white symbols), influents (black symbols) and effluents (grey symbols) of waste water treatment plants in Switzerland $(A, n=93$ values from 9 studies) and Germany (B, $n=95$ values from 10 studies) with maximum values $(\Delta)$ and mean or median values $(0)$ )

sulfamethoxazole, trimethoprim, roxithromycin and clindamycin in Switzerland; sulfamethoxazole, trimethoprim, clarithromycin, erythromycin, roxithromycin and clindamycin in Germany). The reasons for this contradictory picture may be explained by active pharmaceutical ingredients (APIs) excreted as conjugates and then undergoing deconjugation in the WWTPs, ${ }^{[26]}$ by the compilation of values from different studies which cannot be compared directly, by the special management practices of WWTPs with variable removal efficiencies due to different hydraulic retention times, ${ }^{[27]}$ and/or by the lack of removal efficiency of standard WWTPs.

Finally, this survey on detected antibiotics corroborates conclusions from studies of other regions ${ }^{[28-30]}$ that antibiotics are found in WWTP influents and effluents at concentrations of up to and beyond $1000 \mathrm{ng} / \mathrm{L}$, which then decrease to concentrations of $1-100 \mathrm{ng} / \mathrm{L}$ in surface waters.

\subsection{Hazard: Effect Levels of Antibiotics on Monocellular Primary Producers}

Methods: The publicly available literature was screened for publications on effects of antibiotics on eukaryotic algae and/or prokaryotic cyanobacteria. ${ }^{[31-70]}$ Only those studies were used which fulfilled the following requirements: study performance following the OECD TG 201[71] or a comparable protocol, presentation of No-Observed Effect Concentrations NOEC and/or $10 \%$ Effect Concentrations $\mathrm{EC}_{10}$ for growth inhibition, exposure period of 72 or $96 \mathrm{~h}$, data on at least one representative of eukaryotic algae or prokaryotic cyanobacteria.

Results: Overall, 111 endpoint values (either NOEC and/ or $\mathrm{EC}_{10}$ ) were retrieved from tests with seven green algal species (Raphidocelis subcapitata, Desmodesmus subspicatus, D. quadricauda, Scenedesmus quadricauda, S. obliquus, Chlorella vulgaris, Ankistrodesmus fusiformis), three diatom species (Cyclotella meneghiniana, Navicula pelliculosa, Phaeodactylum tricornutum) and four cyanobacterial species (Anabaena flos-aquae, A. sp. CPB4337, Synechococcus leopoliensis, Microcystis aeruginosa). $[31,40,48,51,53,55,58,62-65,67]$

A pair-wise comparison of $\mathrm{NOEC} / \mathrm{EC}_{10}$ of the most sensitive eukaryotic algal species (green algae or diatoms) and the most sensitive prokaryotic cyanobacterial species could be performed for 17 antibiotics (2-14 endpoints per substance) (Table 2).

Cyanobacterial species are more sensitive than eukaryotic algae for 11 antibiotics $(64.7 \%)$, and less sensitive for six antibiotics $(35.3 \%$, clindamycin, levofloxacin, oxytetracycline, metronidazole, tetracycline and trimethoprim).

Regarding the suggestion of the EMA draft ${ }^{[3]}$ to test the species $R$. subcapitata, A. flos-aquae and S. leopoliensis, one of these three species was found to be indeed the most sensitive tested species for 13 of 17 antibiotics (76.5\%). For four antibiotics (23.5\%), less frequently tested species were the most sensitive: two cyanobacterial species $M$. aeruginosa $\left(\mathrm{EC}_{10}=0.007 \mathrm{mg}\right.$ enrofloxacin $\left./ \mathrm{L}\right)$ and Anabaena. sp. CPB4337 ( $\mathrm{EC}_{10}=0.007 \mathrm{mg}$ erythromycin $\left./ \mathrm{L}\right)$, one green algal species A. fusiformis $\left(\mathrm{EC}_{10}=0.05 \mathrm{mg}\right.$ oxytetracycline $/ \mathrm{L})$ and one diatom species $N$. pelliculosa $(\mathrm{NOEC}=1.20 \mathrm{mg}$ trimethoprim/L). These values are less than a factor of 10 different from the endpoint values for the second most sensitive species, which in all cases correspond to one of the species suggested in the EMA draft (A. flos-aquae: $\mathrm{EC}_{10}=0.019 \mathrm{mg}$ enrofloxacin $/ \mathrm{L} ;[43]$ A. flos-aquae: $\mathrm{EC}_{10}=0.03$ mg erythromycin/L; ${ }^{[58]} R$. subcapitata: $\mathrm{EC}_{10}=0.07 \mathrm{mg}$ oxytetracycline/L; ${ }^{[64]} R$. subcapitata: NOEC $=$ $12.5 \mathrm{mg}$ trimethoprim/ $\left.\mathrm{L}^{[46]}\right)$. 
Table 2. Comparison of the most sensitive species of monocellular primary producers towards 17 antibiotics.

\begin{tabular}{|c|c|c|c|c|c|c|c|}
\hline Antibiotic & $\begin{array}{l}\text { Number } \\
\text { of studies }\end{array}$ & $\begin{array}{l}\text { Number of } \\
\text { species tested }\end{array}$ & Most susceptible species & $\begin{array}{l}\text { Expo- } \\
\text { sure [h] }\end{array}$ & $\mathrm{EC}_{10}[\mathrm{mg} / \mathrm{L}]$ & $\begin{array}{l}\text { NOEC } \\
{[\mathrm{mg} / \mathrm{L}]}\end{array}$ & $\begin{array}{l}\text { Litera- } \\
\text { ture }\end{array}$ \\
\hline \multicolumn{8}{|c|}{ Eukaryotic algal species* } \\
\hline Amoxicillin & 2 & 1 & Raphidocelis subcapitata & 72 & $>1500$ & - & [48] \\
\hline Ciprofloxacin & 5 & 4 & Scenedesmus obliquus & 72 & - & 0.0250 & {$[63]$} \\
\hline Clarithromycin & 3 & 2 & Raphidocelis subcapitata & 72 & 0.0070 & 0.0040 & {$[62]$} \\
\hline Clindamycin & 1 & 1 & Raphidocelis subcapitata & 72 & 0.00056 & 0.00029 & {$[67]$} \\
\hline Enrofloxacin & 7 & 4 & Ankistrodesmus fusiformis & 96 & 0.0300 & - & {$[64]$} \\
\hline Erythromycin & 4 & 2 & Raphidocelis subcapitata & 72 & 0.0360 & - & {$[48]$} \\
\hline Flucloxacillin & 1 & 1 & Raphidocelis subcapitata & 72 & $>95,2$ & 0.9500 & {$[67]$} \\
\hline Levofloxacin & 1 & 1 & Raphidocelis subcapitata & 72 & 0.9300 & - & {$[48]$} \\
\hline Lincomycin & 7 & 6 & Desmodesmus subspicatus & 96 & 0.0772 & - & {$[57]$} \\
\hline Linezolid & 1 & 1 & Raphidocelis subcapitata & 72 & 0.1800 & 0.1600 & {$[58]$} \\
\hline Metronidazole & 6 & 2 & Chlorella sp. & 72 & 2.03 & - & {$[31]$} \\
\hline Norfloxacin & 4 & 2 & Raphidocelis subcapitata & 72 & - & 2.00 & {$[40]$} \\
\hline Oxytetracycline & 5 & 3 & Ankistrodesmus fusiformis & 96 & 0.0500 & - & {$[64]$} \\
\hline Sulfamethoxazole & 2 & 1 & Raphidocelis subcapitata & 72 & - & 0.5 & {$[40]$} \\
\hline Tetracycline & 2 & 1 & Raphidocelis subcapitata & 72 & 0.0320 & - & {$[48]$} \\
\hline Trimethoprim & 9 & 5 & Navicula pelliculosa** & 96 & 1.32 & 1.20 & {$[57]$} \\
\hline Tylosin & 7 & 5 & Phaeodactylum tricornutum $* *$ & 96 & 0.1924 & 0.2565 & {$[57]$} \\
\hline \multicolumn{8}{|c|}{ Prokaryotic cyanobacterial species } \\
\hline Amoxicillin & 2 & 2 & Anabaena flos-aquae & 72 & - & 0.0040 & {$[58]$} \\
\hline Ciprofloxacin & 3 & 2 & Anabaena flos-aquae & 72 & - & 0.0026 & {$[58]$} \\
\hline Clarithromycin & 3 & 2 & Synechococcus leopoliensis & 72 & - & 0.0011 & {$[58]$} \\
\hline Clindamycin & 3 & 2 & Synechococcus leopoliensis & 72 & 0.00239 & 0.00029 & {$[67]$} \\
\hline Enrofloxacin & 5 & 2 & Microcystis aeruginosa & 72 & 0.0070 & 0.0090 & {$[65]$} \\
\hline Erythromycin & 2 & 2 & Anabaena sp. CPB4337 & 72 & 0.0050 & - & {$[48]$} \\
\hline Flucloxacillin & 3 & 2 & Anabaena flos-aquae & 72 & 0.11 & 0.03 & {$[67]$} \\
\hline Levofloxacin & 1 & 1 & Anabaena flos-aquae & 72 & 1.1000 & - & [53] \\
\hline Lincomycin & 3 & 2 & Synechococcus leopoliensis & 96 & 0.0081 & - & {$[57]$} \\
\hline Linezolid & 3 & 2 & Synechococcus leopoliensis & 96 & 0.0900 & 0.1000 & {$[67]$} \\
\hline Metronidazole & 3 & 2 & Synechococcus leopoliensis & 72 & 6.88 & 1.00 & {$[67]$} \\
\hline Norfloxacin & 1 & 1 & Anabaena sp. CPB4337 & 72 & 1.20 & - & {$[48]$} \\
\hline Oxytetracycline & 1 & 1 & Anabaena flos-aquae & 72 & 1.50 & - & {$[50]$} \\
\hline Sulfamethoxazole & 3 & 2 & Anabaena flos-aquae & 72 & - & 0.1000 & {$[58]$} \\
\hline Tetracycline & 1 & 1 & Anabaena sp. CPB4337 & 72 & 2.50 & - & {$[48]$} \\
\hline Trimethoprim & 5 & 2 & Anabaena flos-aquae & 96 & 18.3 & 13.6 & {$[57]$} \\
\hline Tylosin & 2 & 2 & Synechococcus leopoliensis & 96 & 0.0101 & 0.0082 & {$[57]$} \\
\hline
\end{tabular}

The values printed in bold indicate the lowest threshold effect concentration for an antibiotic, which would serve as point of departure for the derivation of an environmentally safe level. According to the guideline ${ }^{[3]}$ an $\mathrm{EC}_{10}$ is preferred over a NOEC from the same study. ${ }^{*}$ The original sources may state "Pseudokirchneriella subcapitata" instead of the meanwhile valid new name Raphidocelis subcapitata. ${ }^{* \star D i a t o m . ~}$

\section{Full Primary Producer Datasets According to the EMA Draft Guideline}

In the course of the master thesis of Loetscher, $[67]$ it was intended to compile a small series of primary producer data sets as required by the EMA-guideline ${ }^{[3]}$ draft in order to get some additional evidence of the suitability of the new suggested representative species group.
Using a scheme for the so-called 'calculated antibiotic therapy' (i.e. a therapy in absence of knowledge on the identity of the pathogenic bacterial species, but supported by experience on the respective disease patterns) ${ }^{[72]}$ four listed antibiotics clinically not indicated for any gram-negative bacteria were chosen. Literature data considered suitable for regulatory environmental assessment submissions according to applicable study rating schemes ${ }^{[73,74]}$ for 
two of these antibiotics (clindamycin and linezolid) have been retrieved from publications. The missing endpoints to complete the datasets according to the tailored testing scheme of the EMA guideline draft ${ }^{[3]}$ have been determined experimentally[ ${ }^{[67]}$ according to the recommended test guideline. ${ }^{[71]}$ For the two remaining antibiotics (flucloxacillin and metronidazole) all required endpoints have been determined. ${ }^{[67]}$ Table 3 shows the complete datasets.

\section{Discussion}

\subsection{Risk Assessment on Primary Producers Based on Observed MEC and Measured Effect Levels}

Several caveats regarding the simplifications of the EU ERA assessment approach ${ }^{[2,3]}$ for HMP should be taken into account: firstly, the highly diverse groups of eukaryotic algae and prokaryotic cyanobacteria are so far only represented by a small number of tested species. To further assess the suitability of the EMA draft guideline suggestions, more species should be tested to reduce uncertainty. Secondly, testing of primary producers should be focused on reporting $\mathrm{EC}_{10}$-values in order to reflect adequately the continuously occurring low concentrations of antibiotics in surface waters. And finally, additional studies on effects of antibiotic mixtures at environmentally relevant concentrations are needed for the assessment of the ERA of antibiotics.

The model for the PEC calculation used in the guidelines ${ }^{[2,3]}$ does not take possible background levels of antibiotics into account. Other uses apart from the indications(s) of the API as submitted by the applicant for marketing authorisation as HMP are disregarded and the same API may e.g. be used also in veterinary medicine. Accordingly, MECs can generally be used to replace the estimation of PECs for already marketed APIs and are more relevant as they integrate over all uses and include also environmental depletion and/or liberation from unstable sinks.

On the basis of the literature review RQs can be established for six antibiotics. To this end, the maximum MEC was divided by the derived PNEC for each API. As maximum MEC the higher value of either the concentration directly measured in surface water or the calculated value using the MEC at the WWTP point of release, which equals the effluent MEC/10 considering the dilution as stated in the ERA guideline ${ }^{[2]}$ and in line with the MECs presented here, was considered. The PNEC for primary producers was calculated using the lowest effect threshold on growth rate to the most sensitive freshwater species from Table 2, whereas an existing $\mathrm{EC}_{10}$ was preferred over an NOEC from the same study as suggested by the guideline. ${ }^{[3]}$ This value was divided by a safety factor of 10 in agreement with the ERA guideline ${ }^{[2]}$ to derive the $\mathrm{PNEC}_{\text {primary producers }}$. The PNECs, MECs and the resulting RQs are listed in Table 4.

The data show that clarithromycin can pose a local risk to the primary producer populations in Switzerland and Germany. This is also the case for erythromycin in Germany. Nonetheless, other substances being bioactive through the same or a related mode of action can be able to produce additive or even exponentially increased effects in the environment and are therefore contributing to the total ecotoxicological burden of polluted biotopes.

The ERA according to the EU guideline focuses on the point of release (i.e. near the WWTP effluent) and considers the worst case that $1 \%$ of the population uses an API at the same time. The PEC is intended to represent worst case conditions

Table 3. Threshold toxicity data sets of antibiotics according to the new guideline draft, based on growth rate effects.

\begin{tabular}{|c|c|c|c|}
\hline \multirow[t]{3}{*}{ Antibiotic } & \multicolumn{3}{|c|}{ Test species and their $72 \mathrm{~h} \mathrm{EC}_{10}[\mathrm{mg}$ API/L] } \\
\hline & \multirow{2}{*}{$\begin{array}{c}\text { Green algae } \\
\text { Raphidocelis subcapitata }\end{array}$} & \multicolumn{2}{|c|}{ Cyanobacteria } \\
\hline & & Anabaena flos-aquae & Synechococcus leopoliensis \\
\hline Clindamycin & $\mathbf{0 . 0 0 0 5 6}^{[67] ; \text { IES\#20190190 }}$ & $0.010^{[75]}$ & $0.0029^{[67] ; \text { IES } \# 20190121}$ \\
\hline Flucloxacillin & $>95^{[67] ; \text { IES\#20190122] }}$ & $\mathbf{0 . 1 1}^{[67] ; \text { IES\#20190123* }}$ & $7.7^{[67] ; \text { IES } \# 20190124}$ \\
\hline Linezolid & $\mathbf{0 . 1 8}^{[58]^{* *}}$ & $0.73^{[58]}$ & $0.34^{[67] ; \text { IES\#20190125 }}$ \\
\hline Metronidazole & $13^{[67] ; \text { IES\#20190179] }}$ & $20^{[67] ; \text { IES\#20190126 }}$ & $\mathbf{6 . 9}^{\text {[67]; IES\#20190127 }}$ \\
\hline
\end{tabular}

The internal IES study numbers are given in superscript (after the reference) for easier identification. The values printed in bold indicate the lowest threshold concentration and thus the most sensitive species. ${ }^{*}$ Based on results of the range-finding test $(0.1,1.0,10,100 \mathrm{mg} / \mathrm{L}$ and control, in three replicates).

**The reference states "Pseudokirchneriella subcapitata", the former name of the species.

Table 4. Calculation of risk quotients (RQ) for seven antibiotics found in Switzerland and Germany.

\begin{tabular}{|l|c|c|c|c|c|c|}
\hline Antibiotic & PNEC $[\mu \mathrm{g} / \mathrm{L}]$ & \multicolumn{2}{|c|}{ Max. MEC surface water $\left[\mu \mathrm{g} / \mathbf{L}^{1 *}\right.$} & \multicolumn{2}{|c|}{ RQ } \\
\hline & & Switzerland & Germany & Switzerland & 0.35 \\
\hline Ciprofloxacin & 0.26 & 0.05 & 0.09 & 0.19 & $\mathbf{2 . 3 6}$ \\
\hline Clarithromycin & 0.11 & 0.328 & 0.26 & 0.57 & 0.16 \\
\hline Clindamycin & 0.56 & 0.317 & 0.09 & 0.48 & $\mathbf{3 . 4}$ \\
\hline Erythromycin & 0.50 & 0.24 & 1.7 & 0.002 & no data \\
\hline Norfloxacin & 120 & 0.219 & 8.24 & 0.009 & 0.82 \\
\hline Sulfamethoxazole & 10 & 0.09 & &
\end{tabular}

RQs > 1 are printed in bold. *Either directly determined or calculated as effluent/10 according to the guidelines. 
occurring exceptionally only. Consequently, RQ $>1$ should occur only in exceptional cases, e.g. in an epidemic if more than the guideline default value ${ }^{[2]}$ of $1 \%$ of the population is treated with an API.

Therefore the data presented here may question whether the standard safety factor of 10 and/or the generic assumption of $1 \%$ of the population treated may cover all the simplifications applicable in prospective ERAs as a part of the registration dossier before marketing authorisation. This represents one of the major challenges in the risk assessment process. A simple way to improve the robustness of risk assessment would be the post-approval comparison of PEC and MEC with the requirement of assessment refinement in case the MEC exceeds the PEC regularly and significantly (ecopharmacovigilance). The requirement of dossier update as stated under the REACH - legislation (Regulation (EC) no. 1907/2006) would be helpful to refine the assessment for coping with the real situation. To this end, substance monographs for each problematic API could be compiled e.g. by substance information exchange fora as required under REACH. In conclusion the ERA process for pharmaceutical APIs still has room for improvement.

\subsection{Justification for the Waiving of Fish Testing According to the EMA Guideline Draft Scheme for Antibiotics}

For reasons of therapeutic efficacy and low toxicity, target structures of antibiotics should be specific for the disease-causing prokaryotes, which means that such targets should be absent in multicellular animals (metazoa) including vertebrates. Ideally an adverse outcome pathway (AOP) cannot develop thus resulting in little toxicity to the eukaryotic cells of humans and domestic animals. The experimentally observed impact caused by antibiotics is growth reduction, affecting potentially cyano- and other bacteria, but also photosynthetically active eukaryotes such as algae and multicellular plants (metaphyta). ${ }^{[1,76-78]}$

The latter is plausible as the chloroplasts of eukaryotic plant cells can carry suitable target structures quite similar to the ones in bacteria, which is one of the basic proofs whereupon the endosymbiotic theory is built. ${ }^{[79,80]}$ Genome similarities between plastids, the cell organelles to which also chloroplasts belong, and cyanobacteria have been confirmed. ${ }^{[81]}$

Also the mitochondria, cell organelles present in all eukaryotic cells, carry prokaryotic target structures. An antibiotic should effectively exhibit toxic action against prokaryotic, bacterial cells, but to be safe it should not interact with any targets present in humans and domestic animals. It can be expected that antibiotics with an AOP acting against mitochondria would exhibit intolerable human and domestic animal toxicity and is therefore likely to be sorted out quite early in the development process of a new API.

Humans and domestic animals, being vertebrates, can be assumed to have some similarity to fish in terms of drug targets. This is supported by findings that $>90 \%$ of all human drug targets had orthologues in zebrafish (Danio rerio), while it was $64 \%$ in a water flea (Daphnia pulex) and only $34 \%$ in a green alga (Chlamydomonas reinhardtii).[82]

In conclusion one can expect that antibiotics generally show a low fish toxicity, which also seems to have been confirmed in the data of the dossiers submitted to the authorities. On this basis, it seems that fish testing can indeed be left out of the tailored antibiotic testing scheme as suggested by the EMA guideline draft.[3]

\subsection{Is the new EMA Guideline Protective for Primary Producers?}

The scheme for testing the potential risk of antibiotics to primary producers in the aquatic environment foreseen by the EMA guideline ${ }^{[3]}$ draft is in principle sufficiently protective. In the majority of the comparisons, cyanobacteria were the most sen- sitive phylum, and for 5 of the 17 antibiotics green algae showed a higher sensitivity than cyanobacteria. This is in line with the assumption that antibiotics tend to be more toxic to cyanobacteria, probably because of their greater similarity to the pathogenic bacteria targeted by them. Interestingly trimethoprim was found to be most toxic to a diatom, however not many data for diatoms are published.

No full data set as foreseen in the guideline update ${ }^{[3]}$ could be compiled based on literature data. Therefore new experiments were performed to provide lacking data points for two antibiotics (clindamycin and linezolid) and two completely new data sets for another two antibiotics (flucloxacillin and metronidazole). In summary four full EMA guideline ${ }^{[3]}$ draft-conform datasets (Table 3) for antibiotics not primarily active against gram-negative bacteria and which are therefore not expected to be highly effective against gram-negative cyanobacteria (Table 3), are now available. Interestingly each of the three species to be tested according to the guideline $\mathrm{draft}^{[3]}$ represents in at least one of the tested cases the most sensitive species. Such a finding in a rather small data set of antibiotics can be seen as a hint that the species selection made by the authors of the EMA draft guideline is appropriate, especially as the tested antibiotics have been designed to work against gram-positive bacteria, to which cyanobacteria do not belong to, and as green algae are typically not most sensitive to antibiotics. The green algae showed two times the highest sensitivity, however represented by only one of the three test species, which is a slight overrepresentation. Nonetheless our data do not support the hypothesis that the clinical spectrum of antibiotics may justify a differentiation in the environmental safety testing.

Finally the species selection is also strongly supported in the sense that the genus Synechococcus represents one of the two most important genera (Prochlorococcus and Synechococcus) for global primary production. ${ }^{[83]}$

In view of the significant contribution of waterborne microorganisms to the global primary production ${ }^{[84]}$ and thus oxygen production and carbon dioxide fixation, ${ }^{[85]}$ the potential harm of antibiotic releases is even more undesirable. One critical point in the draft guideline may be the lack of testing requirements for the highly diverse group of diatoms, which is characterised by a quite specific biology and potentially different sensitivity to antibiotics. Their global importance should not be neglected, as the contribution of all diatoms to the annual 45-50 billion tons of biomass production in the oceans is calculated to be about $40 \%$, which means a share of diatoms amounting to about $20 \%$ of the global carbon fixation. ${ }^{[84,86-89]}$

\section{Acknowledgements}

The authors would like to thank Matthias Loetscher, whose master thesis results were used, Anne Dupont for supervising the laboratory work, and the ecotoxicology team of IES for supporting Matthias Loetscher's internship and the competent reviewer for the fruitful comments.

\section{Received: December 6, 2019}

[1] Organisation for Economic Co-operation and Development (OECD), 'Pharmaceutical Residues in Freshwater. Hazards and Policy Responses' OECD Publishing, 2019, doi: 10.1787/c936f42d-en.

[2] European Medicines Agency (EMEA) Committee for Medicinal Products for Human Use (CHMP), 'Guideline on the Environmental Risk Assessment of Medicinal Products for Human use' Self-Published, 2006, in relation with the 'Questions and answers' document, 2016.

[3] European Medicines Agency (EMA) Committee for Medicinal Products for Human Use (CHMP), 'Guideline on the Environmental Risk Assessment of Medicinal Products for Human use. Draft' Self-Published, 2018.

[4] Organisation for Economic Co-operation and Development(OECD), 'Test No. 209: Activated Sludge, Respiration Inhibition Test (Carbon and Ammonium Oxidation)' OECD Publishing, 2010, doi: 10.1787/9789264070080-en. 
[5] A. Popescu, R. J. Doyle, Biotechnic \& Histochemistry 1996, 71, 145, doi: 10.3109/10520299609117151.

[6] E. Hoiczyk, A. Hansel, J. Bacteriol. 2000, 182, 1192, doi: 10.1128/ JB.182.5.1191-1199.2000.

[7] F. Bonvin, R. Rutler, N. Cevre, J. Halder, T. Kohn, Environ. Sci. Technol. 2011, 45, 4720, doi: 10.1021/es2003588.

[8] W. Giger, A. C. Alder, E. M. Golet, H.-P. E. Kohler, C. S. McArdell, E. Molnar, H. Siegrist, M. J.-F. Suter, Chimia 2003, 57, 485, doi: 10.2533/000942903777679064.

[9] A. Göbel, A. Thomsen, C. S. McArdell, A. C. Alder, W. Giger, N. Theiß D. Löffler, T. A. Ternes, J. Chromatogr. A 2005, 1085, 179, doi: 10.1016/j. chroma.2005.05.051.

[10] A. Göbel, C. S. McArdell, A. Joss, H. Siegrist, W. Giger, Sci. Total Environ. 2007, 372, 361, doi: 10.1016/j.scitotenv.2006.07.039.

[11] E. M. Golet, A. Strehler, A. C. Alder, W. Giger, Anal. Chem. 2002, 74, 5455 doi: $10.1021 / \mathrm{ac} 025762 \mathrm{~m}$

[12] E. M. Golet Sancho, PhD Thesis, Eidgenössische Technische Hochschule Zürich, 2002.

[13] A. Joss, E. Keller, A. C. Alder, A. Göbel, C. S. McArdell, T. Ternes, H. Siegrist, Water Res. 2005, 39, 3139, doi: 10.1016/j.watres.2005.05.031.

[14] C. S. McArdell, E. Molnar, M. J.-S. Suter, W. Giger, Environ. Sci. Technol. 2003, 37, 5479, doi: 10.1021/es034368i.

[15] B. Morasch, F. Brown, H. Reiser, D. Gransjean, L. F. de Alencastro, C. Perazzolo, N. Chevre, T. Kohn, Environ. Toxicol. Chem. 2010, 29, 1658, doi: 10.1002/etc. 222 .

[16] R. Alexy, K. Kümmerer, 'Antibiotics for human use' in 'Organic Pollutants in the Water Cycle: Properties, Occurrence, Analysis and Environmental Relevance of Polar Compounds', Eds. T. Reemtsma, M. Jekel, Wiley-VCH, 2006, doi: 10.1002/352760877X.ch3.

[17] T. Christian, R. J. Schneider, H. A. Färber, D. Skutlarek, M. T. Meyer, H. E. Goldbach, Acta Hydroch. Hydrob. 2003, 31, 36, doi: 10.1002/ aheh.200390014.

[18] T. Christian, PhD Thesis, Rheinische Friedrich-Wilhelms-Universität Bonn, 2004.

[19] H.Färber, D. Skutlarek, M.Exner, 'Untersuchung von Krankenhausabwässern eines Universitätsklinikums, von kommunalem Abwaser sowie von Oberflächenwasser und Uferfiltraten auf Rückstände ausgewählter Antibiotika' Rheinische Friedrich-Wilhelms-Universität Bonn, 2003.

[20] C. Hartig, T. Storm, M. Jekel, J. Chromatogr. A 1999, 854, 163, doi: 10.1016/ S0021-9673(99)00378-7.

[21] R. Hirsch, T. Ternes, K. Haberer, K.-L. Kratz, Sci. Total Environ. 1999, 225 109, doi: 10.1016/S0048-9697(98)00337-4.

[22] D. Maier, L Blaha, J. P. Giesy, A. Henneberg, H-R. Köhler, B. Kuch, R Osterauer, K. Peschke, D. Richter, M. Scheurer, R. Triebskorn, Water Res. 2015, 72, 127, doi: 10.1016/j.watres.2014.08.050.

[23] K. Nödler, T. Licha, K. Bester, M. Sauter, J. Chromatogr. A 2010, 1217, 6511 doi: 10.1016/j.chroma.2010.08.048.

[24] J. Rossmann, S. Schubert, R. Gurke, R. Oertel, W. Kirch, J. Chromatogr. B 2014, 969, 162, doi: 10.1016/j.jchromb.2014.08.008.

[25] S. Wiegel, A. Aulinger, R. Brockmeyer, H. Harms, J. Löffler, H. Reincke, R Schmidt, B. Stachel, W. von Tümpling, A. Wanke, Chemosphere 2004, 57 , 107, doi: 10.1016/j.chemosphere.2004.05.017.

[26] R. Mirzaei, M. Yunesian, S. Nasseri, M. Gholami, E. Jalilzadeh, S. Shoeibi, A. Mesdaghinia, Sci. Total Environ. 2018, 619-620, 446, doi: 10.1016/j.scitotenv.2017.07.272.

[27] S. Comber, M. Gardner, P. Sörme, D. Leverett, B. Ellor, Sci. Total Environ. 2018, 613-614, 538, doi: 10.1016/j.scitotenv.2017.09.101.

[28] I. T. Carvalho, L. Santos, Environ. Int. 2016, 94, 736, doi: 10.1016/j.envint.2016.06.025

[29] N. Hanna. P. Sun, Q. Sun, X. Li, X. Yang, X. Ji, H. Zou, J. Ottoson, L. E. Nilsson, B. Berglund, O. J. Dyar, A. J. Tamhankar, C. S. Lundborg, Environ. Int. 2018, 114, 131, doi: 10.1016/j.envint.2018.02.003.

[30] M.-C. Danner, A. Robertson, V. Behrends, J. Reiss, Sci. Total Environ. 2019 664, 793, doi: 10.1016/j.scitotenv.2019.01.406.

[31] P. F. Lanzky, B. Halling-Sørensen, Chemosphere 1997, 35, 2553, doi: 10.1016/S0045-6535(97)00324-X.

[32] B. Halling-Sørensen, Chemosphere 2000, 40, 731, doi: 10.1016/S0045 6535(99)00445-2.

[33] R. Andreozzi, V. Caprio, C. Ciniglia, M. de Champdore, R. L. Guidice, R. Marotta, E. Zuccato, Environ. Sci. Technol. 2004, 38, 6832, doi: 10.1021/ es049509a.

[34] K. Eguchi, H. Nagase, M. Ozawa, Y. S. Endoh, K. Goto, K. Hirata, K Miyamoto, H. Yoshimura, Chemosphere 2004, 57, 1733, doi: 10.1016/j. chemosphere.2004.07.017.

[35] M. Isidori, M. Lavorgna, A. Nardelli, L. Pascarella, A. Parrella, Sci. Total Environ. 2005, 346, 87, doi: 10.1016/j.scitotenv.2004.11.017.

[36] A. A. Robinson, J. B. Beldon, M. J. Lydy, Environ. Toxicol. Chem. 2005, 24 423, doi: 10.1897/04-210R.1.

[37] R. Andreozzi, M. Canterino, R.L. Giudice, R. Marotta, G. Pinto, A. Pollio, Water Res. 2006, 40, 630, doi:10.1016/j.watres.2005.11.023.
[38] T. Ando, H. Nagase, K. Eguchi, T. Hirooka, T. Nakamura, K. Miyamoto, K. Hirata, Environ. Toxicol. Chem. 2007, 26, 601, doi: 10.1897/06-195R.1.

[39] X. Nie, X. Wang, J. Chen, V. Zitko, T. An, Environ. Toxicol. Chem. 2008, 27, 167, doi: 10.1897/07-028.1.

[40] L.-H. Yang, G.-G. Ying, H.-C. Su, J. L. Satuber, M. S. Adams, M. T. Binet, Environ. Toxicol. Chem. 2008, 27, 1201, doi: 10.1897/07-471.1.

[41] H.-T. Lai, J.-H. Hou, C.-I. Su, C.-L. Chen, Ecotoxicol. Environ. Safety 2009 , 72, 329, doi: 10.1016/j.ecoenv.2008.03.005

[42] E. van der Grinten, M. G. Pikkemaat, E.-J. van den Brandhof, G. J. Stroomberg, M. H. S. Kraak, Chemosphere 2010, 80, 1, doi: 10.1016/j. chemosphere.2010.04.011.

[43] I. Ebert, J. Bachmann, U. Kühnen, A. Küster, C. Kussatz, D. Maletzki, C. Schlüter. Environ. Toxicol. Chem. 2011, 30, 12, 2789, doi: 10.1002/etc.678.

[44] H.-C. Holten-Lützhøft, B. Halling-Sørensen, S. E. Jørgensen, Arch. Environ. Contam. Toxicol. 1999, 36, 1, doi: 10.1007/s002449900435.

45] T. Stoichev, M.S. Baptista, M. C. P. Basto, V.M. Vasconcelos, M. T. S. D. Vasconcelos, Ecotoxicol. Environ. Safety 2011, 74, 219, doi: 10.1016/j. ecoenv.2010.10.015

[46] M. De Liguoro, V. Di Leva, M. Dalla Bona, R. Merlanti, G. Caporale, G. Radaelli, Ecotoxicol. Environ. Safety 2012, 82, 114, doi: 10.1016/j. ecoenv.2012.05.016

[47] I. M. Hagenbuch, J. L. Pinckney, Water Res. 2012, 46, 5028, doi: 10.1016/j. watres.2012.06.040.

[48] M. González-Pleiter, S. Gonzalo, I. Rodea-Palomares, F. Leganes, R. Rosal, K. Boltes, E. Marco, F. Fernandez-Pinas, Water Res. 2013, 47, 2050, doi: 10.1016/j.watres.2013.01.020.

[49] X.-P. Nie, B.-Y. Liu, H.-J. Yu, W.-Q. Liu, Y.-F. Yang, Environ. Pollut. 2013, 172, 23, doi: 10.1016/j.envpol.2012.08.013.

[50] D.-J. Huang, J.-H. Hou, T.-F. Kuo, H.-T. Lai, Environ. Toxicol. Pharmacol. 2014, 38, 874, doi: 10.1016/j.etap.2014.09.006.

[51] B. Kolar, L. Arnuš, B. Jeretin, A. Gutmaher, D. Drobne, M. K. Durjava, Chemosphere 2014, 115, 75, doi: 10.1016/j.chemosphere.2014.02.049.

[52] S. M. S. Magalhães, C. M. Brêtas, J. M. Brêtas, G. A. Pianetti, M. W. Franco, F. A. R. Barbosa, Brazilian J. Biol. 2014, 74, S120, doi: 10.1590/15196984.03513

[53] M. Seoane, C. Rioboo, C. Herrero, A. Cid, Marine Environ. Res. 2014, 101, 1, doi: 10.1016/j.marenvres.2014.07.011.

[54] M. Baumann, K. Weiss, D. Maletzki, W. Schüssler, D. Schudoma, W. Kopf, U. Kühnen, Chemosphere 2015, 120, 192, doi: 10.1016/j. chemosphere.2014.05.089.

[55] A. Magdaleno, M.E. Saenz, A.B. Juárez, J. Moretton, Ecotoxicol. Environ. Safety 2015, 113, 72, doi: 10.1016/j.ecoenv.2014.11.021.

[56] E. Geiger, R. Hornek-Gausterer, M. T. Saçan, Ecotoxicol. Environ. Safety 2016, 129, 189, doi: 10.1016/j.ecoenv.2016.03.032.

[57] J. Guo, K. Selby, A. B. A. Boxall, Environ. Toxicol. Chem. 2016, 35, 2587 , doi: 10.1002/etc. 3430 .

[58] A. Coors, P. Vollmar, F. Sacher, A. Thoma, D. Maletzki, C. Polleichtner, P. Schwarz, 'Joint effects of pharmaceuticals and chemicals regulated under REACH in wastewater treatment plant effluents' Umweltbundesamt, 2017.

[59] L. Fu, T. Huang, S. Wang, X. Wang, L. Su, C. Li, Y. Zhao, Chemosphere 2017, 168, 217, doi: 10.1016/j.chemosphere.2016.10.043.

[60] J.-Q. Xiong, M. B. Kurade, J. R. Kim, H.-S. Roh, B.-H. Jeon, J. Hazardous Mater. 2017, 323, 212, doi: 10.1016/j.jhazmat.2016.04.073.

[61] J.-Q. Xiong, M.B. Kurade, B.-H. Jeon, Environ. Pollution 2017, 226, 486, doi: 10.1016/j.envpol.2017.04.044.

[62] T. Yamagishi, Y. Horie, N. Tatarazako, Chemosphere 2017, 174, 1, doi: 10.1016/j.chemosphere.2017.01.071.

[63] M. Załęska-Radziwiłł, K. Affek, N. Doskocz, J. Environ. Sci. Health A 2017, 52, 1233, doi: 10.1080/10934529.2017.1356199.

[64] S. Carusso, A. B. Juarez, J. Moretton, A. Magdaleno, Chemosphere 2018, 194, 821, doi: 10.1016/j.chemosphere.2017.12.047.

[65] A. Rico, W. Zhao, F. Gillissen, M. Lürling, P. J. Van den Brink, Ecotoxicol. Environ. Safety 2018, 148, 228, doi: 10.1016/j.ecoenv.2017.10.010.

[66] M. Sendra, A. Damian-Serrano, C. V. M. Araujo, I. Moreno-Garrido, J. Blasco, Aquatic Toxicol. 2018, 204, 190, doi: 10.1016/j.aquatox.2018.09.008.

[67] M. Loetscher, Master Thesis, Université de Lorraine, 2019.

[68] J.-Q. Xiong, S.-J. Kim, M. B. Kurade, S. Govindwar, R. A. I. Abou-Shanab, J.-R. Kim, H.-S. Roh, M. A. Khan, B.-H. Jeon, J. Hazardous Mater. 2019 , 370, 138, doi: 10.1016/j.jhazmat.2018.07.049.

[69] Q. Xiong, L.-X. Hu, Y.-S. Liu, T.-T. Wang, G.-G. Ying, Aquatic Toxicol. 2019, 207, 197, doi: 10.1016/j.aquatox.2018.12.017

[70] Y. Zhang, J. Guo, T. Yao, Y. Zhang, X. Zhou, H. Chu, Sci. Rep. 2019, 9, 1624, doi: 10.1038/s41598-018-36609-4.

[71] Organisation for Economic Co-operation and Development (OECD), 'Test No. 201: Freshwater Alga and Cyanobacteria, Growth Inhibition Test' OECD Publishing, 2011, doi: 10.1787/9789264069923-en.

[72] AMBOSS GmbH, Berlin, Germany, 'Antibiotika-Mosaik' available from URL https://www.amboss.com/de/aerztliche-pdfs/antibiotika-mosaik, last visited 2020-01-15.

[73] H. J. Klimisch, M. Andreae, U. Tillmann, Regul. Toxicol. Pharmacol. 1997, 25, 1, doi: 10.1006/rtph.1996.1076. 
[74] A. Küster, J. Bachmann, U. Brandt, I. Ebert, S. Hickmann, J. KleinGoedicke, G. Maack, S. Schmitz, E. Thumm, B. Rechenberg, Regul. Toxicol. Pharmacol. 2009, 55, 276, doi: 10.1016/j.yrtph.2009.07.005.

[75] M. Baumann, K. Weiß, W. Kopf, W. Schüssler, 'Biologische Wirktests - polare Spurenstoffe' Bayerisches Landesamt für Umwelt, 2014.

[76] J. Guo, A. Boxall, K. Selby, Crit. Rev. Environ. Sci. Technol. 2015, 45, 2565, doi: 10.1080/10643389.2015.1061873.

[77] C. Roose-Amsaleg, A. M. Laverman, Environ. Sci. Pollut. Res. 2016, 23, 4000, doi: 10.1007/s11356-015-4943-3.

778] R. A. Brain, M. L. Hanson, K. R. Solomon, B. W. Brooks, 'Aquatic plants exposed to pharmaceuticals: effects and risks' in 'Reviews of Environmental Contamination and Toxicology, vol. 192', Ed. D.M. Whitacre, Springer, 2008, doi: 10.1007/978-0-387-71724-1 3.

[79] J. de Vries, J. M. Archibald, Curr. Biol. 2017, 27, R103, doi: 10.1016/j. cub.2016.12.006.

[80] G. I. McFadden, Plant Physiol. 2001, 125, 50, doi: 10.1104/pp.125.1.50.

[81] T. Dagan, M. Roettger, K. Stucken, G. Landan, R. Koch, P. Major, S. B. Gould, V. V. Goremykin, R. Rippka, N. Tandeau de Marsac, M. Gugger, P. J. Lockhart, J. F. Allen, I. Brune, I. Maus, A. Pühler, W.F. Martin, Genome Biol. Evol. 2013, 5, 31, doi: 10.1093/gbe/evs117.

[82] L. Gunnarsson, J. R. Snape, B. Verbruggen, S. F. Owen, E. Kristiansson, L. Margiotta-Casalucie, T. Österlund, K. Hutchinson, D. Leverett, B. Marks, C. R. Tyler, Environ. Int. 2019, 129, 320, doi: 10.1016/j.envint.2019.04.075.

[83] P. Flombaum, J. L. Gallegos, R. A. Gordillo, J. Rincón, L. L. Zabala, N. Jiao, D. M. Karl, W. K. Li, M.W. Lomas, D. Veneziano, C. S. Vera, J. A. Vrugt, A. C. Martiny, Proc. Natl. Acad. Sci. USA 2013, 110, 9824, doi: 10.1073/ pnas. 1307701110.

[84] C. B. Field, M. J. Behrenfeld, J. T. Randerson, P. G. Falkowski, Science 1998, 281, 237, doi: 10.1126/science.281.5374.237.

[85] K. R. Arrigo, D.H. Robinson, D. L. Worthen, R. B. Dunbar, G. R. DiTullio, M. VanWoert, M. P. Lizotte, Science 1999, 283, 365, doi: 10.1126/science.283.5400.365.
[86] E. V. Armbrust, J. A. Berges, C. Bowler, B. R. Green, D. Martinez, N. H. Putnam, S. Zhou, A. E. Allen, K. E. Apt, M. Bechner, M. A. Brzezinski, B. K. Chaal, A. Chiovitti, A. K. Davis, M. S. Demarest, J. C. Detter, T. Glavina, D. Goodstein, M. Z. Hadi, U. Hellsten, M. Hildebrand, B. D. Jenkins, J. Jurka, V. V. Kapitonov, N. Kröger, W. W. Lau, T. W. Lane, F. W. Larimer, J. C. Lippmeier, S. Lucas, M. Medina, A. Montsant, M. Obornik, M. S. Parker, B. Palenik, G. J. Pazour, P. M. Richardson, T. A. Rynearson, M. A. Saito, D. C. Schwartz, K. Thamatrakoln, K. Valentin, A. Vardi, F. P. Wilkerson, D. S. Rokhsar, Science 2004, 306, 79, doi: 10.1126/science.1101156.

[87] D. M. Nelson, P. Tréguer, M. A. Brzezinski, A. Leynaert, B. Quéguiner, Global Biogeochem. Cycles 1995, 9, 359, doi: 10.1029/95GB01070.

[88] D. G. Mann, Phycologia 1999, 38, 437, doi: 10.2216/i0031-8884-38-6437.1.

[89] M. A. Brzezinski, C. J. Pride, V. M. Franck, D. M. Sigman, J. L. Sarmiento, K. Matsumoto, N. Gruber, G. H. Rau, K. H. Coale, Geophys. Res. Lett. 2002, 29, 5, doi: 10.1029/2001GL014349.

\section{License and Terms}

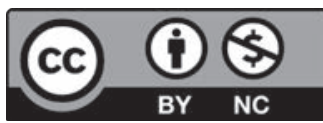

This is an Open Access article under the terms of the Creative Commons Attribution License CC BY_NC 4.0. The material may not be used for commercial purposes.

The license is subject to the CHIMIA terms and conditions: (http:// chimia.ch/component/sppagebuilder/?view=page \&id=12).

The definitive version of this article is the electronic one that can be found at doi:10.2533/chimia.2020.183 